\title{
Glucocorticoids Induce Transcription and Expression of the $\alpha 1 B$ Adrenergic Receptor Gene in DTT1 MF-2 Smooth Muscle Cells
}

\author{
Motoyoshi Sakaue and Brian B. Hoffman \\ Department of Medicine, Stanford University School of Medicine; and the Veterans Affairs Medical Center, Palo Alto, California 94304
}

\begin{abstract}
Steroid hormones modulate physiological processes by a number of mechanisms including regulation of gene expression. We wondered if glucocorticoids might induce expression of $\alpha 1$ adrenergic receptors, which could contribute to the increased sensitivity of vascular smooth muscle to catecholamines that may occur with glucocorticoid excess. We examined the effects of dexamethasone on the expression of the $\alpha 1 B$ adrenergic receptor gene in DDT1 MF-2 smooth muscle cells. Dexamethasone $\left(10^{-6} \mathrm{M}\right)$ produced a 1.8 \pm 0.2 -fold increase in expression of $\alpha 1 \mathrm{~B}$ receptors determined with $\left[{ }^{3} \mathrm{H}\right]$ prazosin. Steady-state values of $\alpha 1 B$ adrenergic receptor mRNA, analyzed by Northern blotting, increased $2.8 \pm 0.7$-fold after 48 h exposure to dexamethasone. This effect of dexamethasone occurred in the presence of the protein synthesis inhibitor cycloheximide. $\alpha 1 \mathrm{~B}$ receptor mRNA abundance was also increased by testosterone and aldosterone, whereas $\beta$ estradiol and progesterone had no effect. The $\alpha 1 B$ receptor gene transcription rate, determined in nuclear run-off assays, increased 2.6 $\mathbf{0 . 6}$-fold in cells treated with dexamethasone for $24 \mathrm{~h}$. The half-life of the $\alpha 1 \mathrm{~B}$ receptor mRNA was unchanged by dexamethasone. These data indicate that glucocorticoids regulate expression of $\alpha 1 B$ receptors by increasing the rate of transcription of this gene. (J. Clin. Invest. 1991. 88:385-389.) Key words: steroid hormones • blood vessels $\bullet$ mRNA $\bullet$ testosterone $\bullet$ aldosterone
\end{abstract}

\section{Introduction}

The majority of patients with Cushing's syndrome (glucocorticoid excess) have hypertension. The mechanism for hypertension in these patients is uncertain but is very likely due to several different effects of glucocorticoids (1). High concentrations of cortisol promote sodium retention and may activate the renin-angiotensin system. Also, glucocorticoids may decrease activity of prostaglandin and kallikrein-kinin systems that both tend to promote vasodilitation (1). It has been consistently observed, both in experimental animals and patients, that glucocorticoids enhance vasoconstriction mediated by catecholamines (2-4).

Catecholamines, such as epinephrine and norepinephrine, promote vasoconstriction by activating $\alpha$ adrenergic receptors in vascular smooth muscle. These effects are mediated by $\alpha 1$

Address correspondence and reprint requests to Dr. Brian B. Hoffman, Veterans Affairs Medical Center, GRECC 182 B, 3801 Miranda Avenue, Palo Alto, CA 94304.

Dr. Sakaue's present address is Department of Internal Medicine (2), Kobe University School of Medicine, Chuo-ku, Kobe 650, Japan. Received for publication 31 January 1991 and in revised form 20 March 1991.

The Journal of Clinical Investigation, Inc.

Volume 88, August 1991, 385-389 adrenergic receptors although $\alpha 2$ adrenergic receptors may also contribute to vasoconstriction. Pharmacological studies have demonstrated that there are several subtypes of $\alpha 1$ receptors; the most extensively described subtypes have been termed $\alpha 1 \mathrm{~A}$ and $\alpha 1 \mathrm{~B}$ adrenergic receptors (5). This demarcation between these two subtypes of $\alpha 1$ receptors is based on differential sensitivity of $\alpha 1$ adrenergic receptor-mediated responses to $\alpha 1$ agonists and antagonists as well as on different requirements of $\alpha 1$ adrenergic receptor-induced responses for extracellular calcium (6). $\alpha 1 \mathrm{~B}$ receptors are sensitive to the irreversible antagonist chlorethylclonidine and do not require extracellular calcium to activate smooth muscle contraction. Molecular cloning experiments have also revealed heterogeneity of $\alpha 1$ adrenergic receptors; the $\alpha 1 \mathrm{~B}$ receptor has been cloned from a cDNA from hamster DTT1 MF2 smooth muscle cells $(7,8)$.

Steroid hormones are well known to mediate physiological and developmental effects in higher eukaryotes by the regulation of gene expression (9). When activated by the appropriate hormone, steroid receptor proteins are thought to interact with specific target genes and modulate transcription of these genes. Glucocorticoids have been shown to induce transcription of $\beta$ adrenergic receptor genes $(10,11)$ and indeed to increase expression of $\beta$ adrenergic receptors in vascular smooth muscle cells in culture (12). We wondered if glucocorticoids might increase expression of $\alpha 1 \mathrm{~B}$ adrenergic receptors in smooth muscle. Using DDT1 MF2 cells as a model system, we have found that glucocorticoids induce expression of the $\alpha 1 \mathrm{~B}$ adrenergic receptor gene.

\section{Methods}

Materials. Reagents for these studies were purchased as follows: dexamethasone, hydrocortisone, aldosterone, testosterone, $\beta$-estradiol, and progesterone from Sigma Chemical Co. (St. Louis, MO); $\left[{ }^{32} \mathrm{P}\right] \mathrm{dCTP}$, $\left.{ }^{32} \mathrm{P}\right] U T P$, nylon filters, and random primer labeling system from Amersham Corp. (Arlington Heights, IL); $\left[{ }^{3} \mathrm{H}\right]$ prazosin $(19.8 \mathrm{Ci} /$ mmol) from New England Nuclear (Boston, MA); pGEM plasmid, RNase-free DNase I, and T7-RNA polymerase from Promega Corp. (Madison, WI); RNase A, RNase T1, proteinase K, and actinomycin D from Boehringer Mannheinn Biochemicals (Indianapolis, IN); restriction enzymes from New England Biolabs (Beverly, MA); cell culture medium and new born bovine serum from Gibco Laboratories (Grand Island, NY). All other compounds were reagent or molecular biology grade.

Cell culture. DDT1 MF2 hamster smooth muscle cells (a gift of Dr. J. Norris and Dr. L. Cornet, University of Arkansas) were maintained in Dulbecco's Modified Eagle's Medium containing streptomycin, penicillin-G, and $10 \%$ heat-inactivated new born bovine serum at $37^{\circ} \mathrm{C}$ in air containing $5 \% \mathrm{CO}_{2}$. The cells were seeded in 100 -mm dishes at a low density, with confluence being reached $\sim 5-6 \mathrm{~d}$ later. The medium was replaced every 3-4 d. $5 \mathrm{~d}$ after seeding, cells were harvested and used for RNA isolation or membrane preparations.

Radioligand receptor binding assay. After the addition of dexamethasone or ethanol vehicle, DDT1-MF2 cells were harvested by centrifugation, suspended in $50 \mathrm{mM}$ Tris- $\mathrm{HCl}$ ( $\mathrm{pH} 7.5$ ), and homogenized with 
a Polytron homogenizer. The pellet obtained by centrifugation for 10 min at $45,000 \mathrm{~g}$ was washed twice with the same buffer and resuspended in the buffer. Total binding was determined by incubating 200 $\mu \mathrm{l}$ of membrane suspension (50-100 $\mu \mathrm{g}$ protein) with $0.1-10 \mathrm{nM}$ of $\left[{ }^{3} \mathrm{H}\right]$ prazosin in a $600 \mu \mathrm{l}$ volume of $50 \mathrm{mM}$ Tris- $\mathrm{HCl}$ buffer. Nonspecific binding was determined in the presence of $10 \mu \mathrm{M}$ phentolamine. After $30 \mathrm{~min}$ of incubation at $25^{\circ} \mathrm{C}, 5 \mathrm{ml}$ of ice-cold buffer was added into each tube and immediately filtered through a Whatman Inc. GF/B fiberglass filter (Clifton, $\mathrm{NJ}$ ). The retained radioactivity was measured using a liquid scintillation counter. Protein concentrations were determined by the modified Lowry's method (13). Receptor density $\left(B_{\max }\right.$ values) for $\left[{ }^{3} \mathrm{H}\right]$ prazosin was calculated from Scatchard plots.

$R N A$ preparation and Northern blotting. Total cellular RNA was isolated by the $\mathrm{LiCl} /$ Urea method (14). Briefly, after rinsing with cold calcium-magnesium free phosphate buffered saline, cells were homogenized in $3 \mathrm{M} \mathrm{LiCl}$ and $6 \mathrm{M}$ Urea, and incubated overnight at $4^{\circ} \mathrm{C}$. RNA was pelleted by centrifugation at $12,000 \mathrm{~g}$ for $20 \mathrm{~min}$. After extraction with phenol/chloroform, and precipitation with ethanol, poly $(\mathrm{A})^{+}$ RNA was purified by oligo(dT) cellulose column chromatography (15). For Northern blot analysis, poly(A) ${ }^{+}$RNA $(2 \mu \mathrm{g})$ was denatured with $6 \%$ formaldehyde, fractionated by $1 \%$ agarose gel electrophoresis, and transferred to a nylon filter. The blot was prehybridized in $50 \%$ formamide, $5 \times$ SSPE buffer, $5 \times$ Denhardt's solution, $0.5 \% \mathrm{SDS}$, at $42^{\circ} \mathrm{C}$ for $4 \mathrm{~h}$, and hybridized at $42^{\circ} \mathrm{C}$ for $12-16 \mathrm{~h}$ to $\alpha 1 \mathrm{~B}$ adrenergic receptor cDNA (a gift from Dr. Robert J Lefkowitz and colleagues at Duke University), utilizing the $0.45-\mathrm{kbp}$ Bgll-Bgll fragment in coding region (7) or $\beta$-actin cDNA (16) probes that were labeled by with ${ }^{32} \mathrm{P}$-dCTP. After hybridization, the filter was washed in $0.1 \times$ SSPE, 0.1\% SDS at $65^{\circ} \mathrm{C}$, and exposed to Kodak XAR- 5 film at $-80^{\circ} \mathrm{C}$ with intensifying screen generally for 18-24 $\mathrm{h}$. The autoradiograms were scanned using a densitometer.

Nuclear run-off transcription assay. Nuclei were prepared as described by Greenberg et al. (17) and stored at $-80^{\circ} \mathrm{C}$. Nuclei (2-3 $\times 10^{7}$ ) were incubated for $20 \mathrm{~min}$ at $30^{\circ} \mathrm{C}$ with $200 \mu \mathrm{Ci}$ of [ $\left.{ }^{32} \mathrm{P}\right] \mathrm{UTP}$. After RNase-free DNase I and proteinase $\mathrm{K}$ treatments, the reaction products were extracted with phenol/chloroform and unincorporated [ $\left.{ }^{32} \mathrm{P}\right]$ UTP was removed by trichloroacetic acid precipitation and filtration. The radiolabeled RNA $\left(2-3 \times 10^{7} \mathrm{cpm}\right)$ was dissolved in $1 \mathrm{ml}$ of hybridization solution (same as above) and hybridized at $42^{\circ} \mathrm{C}$ for $36 \mathrm{~h}$ with $5 \mu \mathrm{g}$ of the pGEM- $4 \mathrm{Z}$ plasmid immobilized to a nylon filter (as a control) or with immobilized plasmid-containing inserts of $\alpha 1 \mathrm{~B}$ adrenergic receptor or $\beta$-actin cDNA. After autoradiography, each dot was cut out and quantified by liquid scintillation counter.

Transcript stability analysis. The stability of $\alpha 1 \mathrm{~B}$ adrenergic receptor mRNA in dexamethasone-treated and control DDT1-MF2 cells was measured by incubating the cells with $5 \mu \mathrm{g} / \mathrm{ml}$ actinomycin $\mathrm{D}$ to block transcription (18). After various times of incubation, total RNA was isolated from individual dishes of these actinomycin D-treated cells as described above and an RNase protection assay was performed. An RNA probe was produced by incubating a pGEM-3Z plasmid that contained a 0.35 -kbp DNA fragment from the $\alpha 1 \mathrm{~B}$ adrenergic receptor cDNA with T7-RNA polymerase and $\left.{ }^{32} \mathrm{P}\right] \mathrm{UTP}(100 \mu \mathrm{Ci})$ at $37^{\circ} \mathrm{C}$ for 1 h. The RNA probe $\left(5 \times 10^{5} \mathrm{cpm}\right)$ and total RNA $(25-50 \mu \mathrm{g})$ were mixed and hybridized overnight at $45^{\circ} \mathrm{C}$ in $80 \%$ formamide, $0.4 \mathrm{M}$ $\mathrm{NaCl}, 50 \mathrm{mM}$ Pipes, and $1 \mathrm{mM}$ EDTA. RNase buffer containing RNase $A(10 \mu \mathrm{g} / \mathrm{ml})$ and $R$ ase $\mathrm{T} 1(10 \mathrm{U} / \mathrm{ml})$ was added to each assay tube and then incubated for $30 \mathrm{~min}$ at $30^{\circ} \mathrm{C}$. RNase-resistant hybrids were precipitated with ethanol and run on a $5 \%$ polyacrylamide, $8 \mathrm{M}$ urea gel.

Statistical analysis. Student's $t$ test (two tailed) was used for comparing groups.

\section{Results}

To investigate the effects of glucocorticoids on $\alpha 1 \mathrm{~B}$ adrenergic receptors, DDT1-MF2 cells were incubated with $10^{-6} \mathrm{M}$ dexa-

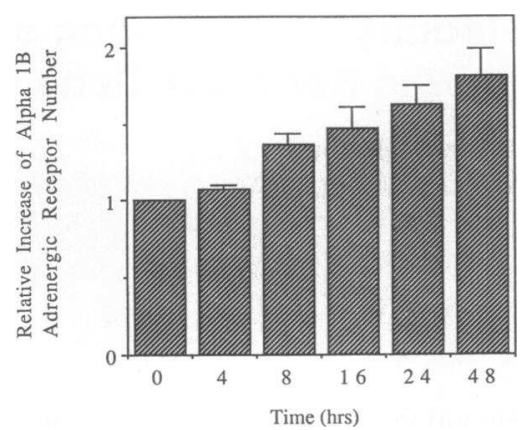

Figure 1. Time course of changes in $\alpha 1 \mathrm{~B}$ adrenergic receptor number induced by dexamethasone. DDT1MF2 cells were exposed to dexamethasone $(1 \mu \mathrm{M})$ for 4-48 h. $\alpha 1 B$ adrenergic receptor density ( $B_{\max }$ value) was measured with $\left[{ }^{3} \mathrm{H}\right]$ prazosin $(0.1-10$ nM). The $B_{\max }$ value was calculated from Scatchard plots. The data shown are the average \pm SEM of at least three experiments.

methasone for 1-48 $\mathrm{h}$ before harvesting the cells. As shown in Fig. 1, $\alpha 1 \mathrm{~B}$ adrenergic receptor number, measured with the ligand $\left[{ }^{3} \mathrm{H}\right]$ prazosin, was unchanged during the first several hours of exposure. The $B_{\max }$ was initially $460 \pm 30 \mathrm{fmol} / \mathrm{mg}$ protein $(n=3)$. The receptor number was found to be increased after 8-16 $\mathrm{h}$ of exposure to dexamethasone and progressively increased to $181 \pm 18 \%$ of controls at $48 \mathrm{~h}(n=4, P<0.05)$. $\left[{ }^{3} \mathrm{H}\right]$ prazosin's dissociation constant did not change (data not shown).

The steady-state $\alpha 1 \mathrm{~B}$ adrenergic receptor mRNA level was measured by Northern blot analysis. Two sizes of $\alpha 1 \mathrm{~B}$ adrenergic receptor mRNA signal were observed in DDT1-MF2 mRNA (2.3 and $2.0 \mathrm{kbp}$ ), and these showed the same relative proportions throughout the experiments involving treatment with steroids (Fig. $2 \mathrm{~A}$ ). As both signals were positive even after washing filters at high stringency in $0.1 \times \mathrm{SSPE}$ at $65^{\circ} \mathrm{C}$, these different sizes could be due to alternative polyadenylation although this was not directly determined. We have observed an increase in the $\alpha 1 \mathrm{~B}$ adrenergic receptor mRNA as early as $2-4$ $h$ after treatment with dexamethasone, and the abundance of the mRNA progressively increased over the next hours (Fig. 2 $A$ ). The maximal accumulation was found at 24-48 $\mathrm{h}$.

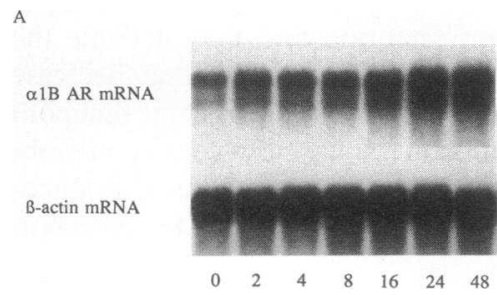

Figure 2. Time course of changes in $\alpha 1 \mathrm{~B}$ adrenergic receptor mRNA abundance after addition of dexamethasone $(1 \mu \mathrm{M})$ for $2-48 \mathrm{~h}$. (A) mRNA abundance was determined by Northern blotting using $\alpha 1 \mathrm{~B}$ adrenergic receptor

B

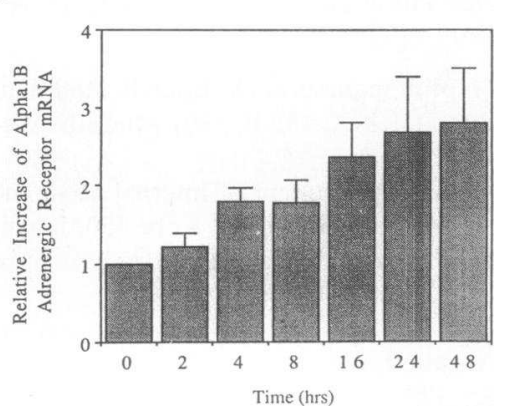
$A R)$ CDNA probe and $\beta$-actin cDNA probe. The autoradiograms were scanned using a densitometer. (B) $\alpha 1$ B adrenergic receptor mRNA is expressed relative to $\beta$-actin mRNA on the same filter. The results are average \pm SEM of three experiments. 
Throughout the experimental period there was no change in abundance of $\beta$-actin mRNA (Fig. $2 A$ ). Therefore, we used $\beta$-actin mRNA as an internal control for minor fluctuations in mRNA applied to the gel. Fig. $2 B$ illustrates the relative increase in $\alpha 1 \mathrm{~B}$ adrenergic receptor mRNA/ $\beta$-actin mRNA ratio. The maximal increase in $\alpha 1 \mathrm{~B}$ adrenergic receptor mRNA from three experiments was $2.8 \pm 0.7$-fold at $48 \mathrm{~h}(n=3, P$ $<0.05$ ).

We also examined changes in $\alpha 1 \mathrm{~B}$ adrenergic receptor mRNA abundance induced by other steroid hormones, including aldosterone, testosterone, $\beta$-estradiol, and progesterone. To compare the potency and efficacy of each of these steroid hormones to induce $\alpha 1 \mathrm{~B}$ adrenergic receptor mRNA abundance, the cells were incubated with varying concentrations of each steroid hormone for 24 h. As shown in Fig. 3, dexamethasone and testosterone have the greatest and most potent capacity to induce the steady-state $\alpha 1 \mathrm{~B} \mathrm{mRNA}$ level; $\mathrm{EC}_{50} \mathrm{~s}$ were $2 \times 10^{-10}$ and $3 \times 10^{-10} \mathrm{M}$, respectively $(n=4)$. Aldosterone's $\mathrm{EC}_{50}$ was $\sim 100$-fold less than that of dexamethasone. These results suggest that $\alpha 1 \mathrm{~B}$ adrenergic receptor mRNA is induced by both glucocorticoids and androgen receptors and possibly by mineralocorticoid receptors as well. However, the activation by aldosterone could reflect an effect mediated via a glucocorticoid receptor.

To investigate if the glucocorticoid-mediated effects required new protein synthesis, DDT1-MF2 cells were pretreated with cycloheximide $(5 \mu \mathrm{g} / \mathrm{ml})$ for $2 \mathrm{~h}$, and then dexamethasone was added to the medium for $24 \mathrm{~h}$. As before, $\alpha 1 \mathrm{~B}$ adrenergic receptor mRNA values were determined by Northern blotting. The yield of mRNA from the cycloheximide-treated cells was $\sim 50 \%$ of that from cells that had not been exposed to the protein synthesis inhibitor; in addition, the proportion of the two signals was different in the cycloheximide-treated cells. Nonetheless, dexamethasone caused the same increase in $\alpha 1 \mathrm{~B}$ adrenergic receptor mRNA in cells treated with cycloheximide, as was observed in control cells treated with this glucocorticoid (Fig. 4).

A change in abundance of the $\alpha 1 \mathrm{~B}$ adrenergic receptor mRNA could result from either an alteration in the transcription rate or degradation rate of the mRNA. To investigate these possibilities, nuclear run-off transcription assays (to measure changes in the transcription rate of the $\alpha 1 \mathrm{~B}$ adrenergic receptor gene) and transcript stability assays were performed. The results of these experiments were normalized to the rate of transcription of the $\beta$-actin gene which was unchanged.

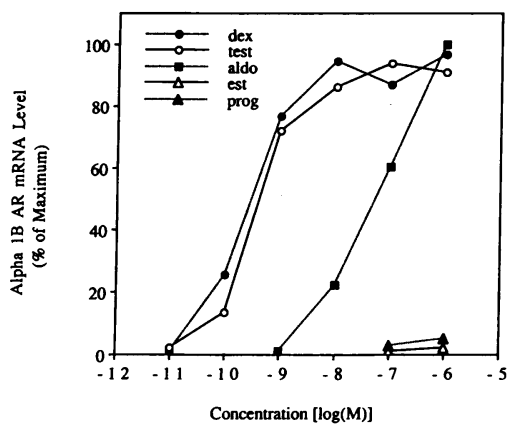

Figure 3. Dose response of effects of steroid hormones on $\alpha 1 \mathrm{~B}$ adrenergic receptor mRNA abundance in DDT1MF2 cells. Cells were exposed to dexamethasone $($ dex $)$, testosterone (test), aldosterone (aldo), $\beta$-estradiol (est), and progesterone (prog) for $24 \mathrm{~h}$. mRNA abundance was determined by Northern blotting as described in the text. Data are the average of three experiments.

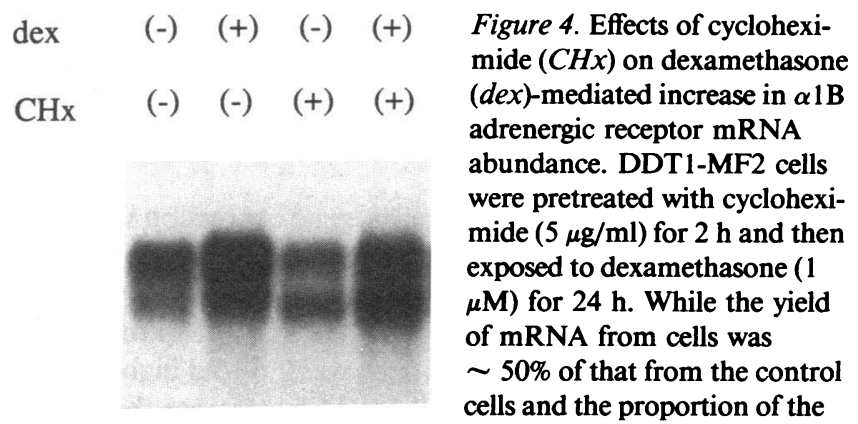

two $\alpha 1 \mathrm{~B}$ signals was altered after $26 \mathrm{~h}$ treatment with cycloheximide, dexamethasone increased $\alpha 1 \mathrm{~B}$ adrenergic receptor mRNA abundance to a similar extent as in the control cells.

The rate of transcription of the $\alpha 1 \mathrm{~B}$ adrenergic receptor gene increased 2.6 \pm 0.6 -fold $(n=4)$ in the cells that had been exposed to dexamethasone for $24 \mathrm{~h}$ (Fig. $5 \mathrm{~A}$ ). This change is similar to the increase in $\alpha 1 \mathrm{~B}$ adrenergic receptor mRNA abundance measured in the Northern blotting experiments.

The stability of the $\alpha 1 \mathrm{~B}$ adrenergic receptor mRNA was examined by inhibiting new mRNA transcription with actinomycin $D$ in intact cells. After incubating the cells with dexamethasone $\left(10^{-6} \mathrm{M}\right)$ for $24 \mathrm{~h}$, actinomycin $\mathrm{D}$ was added at a final concentration of $5 \mu \mathrm{g} / \mathrm{ml}$, and the disappearance of $\alpha 1 \mathrm{~B}$ adrenergic receptor mRNA with time was measured by the RNase protection assay. The yield of total RNA obtained from the cells was unchanged by actinomycin $D$ for up to $8 \mathrm{~h}$. These experiments demonstrated that $\alpha 1 \mathrm{~B}$ receptor mRNA from cells treated with dexamethasone for $24 \mathrm{~h}$ had almost identical stability compared to control cells (5.1 vs. 5.3 h) (Fig. 5 B).

\section{Discussion}

We used the DDT1-MF2 hamster smooth muscle cell line to investigate the regulation of the $\alpha 1 \mathrm{~B}$ adrenergic receptor gene by steroid hormones. DDT 1 MF 2 cells express $\alpha 1, \beta 2$ adrenergic receptors, and glucocorticoid and androgen receptors (1922). In this study, we have demonstrated that $\alpha 1 \mathrm{~B}$ adrenergic receptor number and mRNA abundance in DDT1-MF2 cells is induced by glucocorticoid. This change in expression of the $\alpha 1 \mathrm{~B}$ mRNA is due to an elevated transcription rate of the $\alpha 1 \mathrm{~B}$
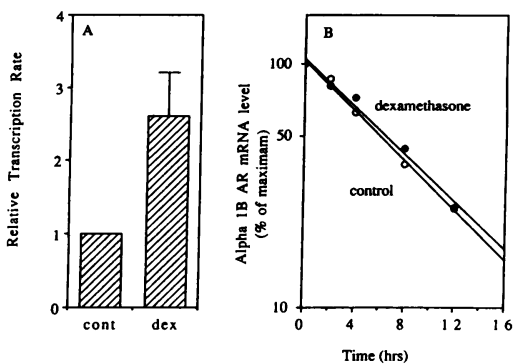

Figure 5. Effects of dexamethasone on $(A)$ transcription rate of the $\alpha 1 B$ adrenergic receptor gene and $(B)$ stability of $\alpha 1 \mathrm{~B}$ receptor mRNA. (A) Cells were treated with dexamethasone (1 $\mu \mathrm{M})$ for $24 \mathrm{~h}$, and the nuclei were isolated. The transcription rate was measured by a nu-

clear run-off assay. Transcription rates of $\alpha 1 \mathrm{~B}$ adrenergic receptor gene are expressed relative to the $\beta$-actin transcription rate. The results are the means \pm SEM, $n=4$ experiments. $(B)$ Stability of $\alpha 1 B$ adrenergic receptor $\mathrm{mRNA}$ was estimated by inhibiting gene transcription with actinomycin $\mathrm{D}(5 \mu \mathrm{g} / \mathrm{ml})$. The decay of $\alpha 1 \mathrm{~B}$ adrenergic receptor mRNA abundance was detected by RNase protection assay. The data shown are the average of three experiments. 
adrenergic receptor gene. Testosterone, a male sex steroid, and aldosterone, a mineralocorticoid, also induced increased abundance of the $\alpha 1 \mathrm{~B}$ adrenergic receptor mRNA. The female sex steroids $\beta$ estradiol and progesterone did not increase expression of this gene.

For most steroid-regulated genes, gene expression is mainly influenced by changing the transcription rate (23), but significant differences in the stability of mRNA, such as ovalbumin mRNA by estrogen (24), have been reported. The transcription rate of $\alpha 1 \mathrm{~B}$ adrenergic receptor gene was 2.6-fold higher in the cells treated with glucocorticoid for $24 \mathrm{~h}$, whereas there is almost no change in stability of the mRNA, indicating that the main change induced by dexamethasone was on gene transcription.

Steroid hormones appear to mediate their biological effects by binding to an intracellular receptor protein that is confined to target cells. Interaction of the hormone and its receptor leads to an alteration in the structure of the protein that is manifested by an increased affinity of the steroid-receptor complex to DNA (23).

Expression of the structurally related $\beta 2$ adrenergic receptor which activates adenylyl cyclase, has been found to be regulated by glucocorticoids $(10,11)$. Glucocorticoids increase the rate of transcription of this gene (10) although the pattern of change in expression for this gene is different from the $\alpha 1 \mathrm{~B}$ adrenergic receptor gene reported here. For the $\beta$ adrenergic receptor, there is a very rapid rise in mRNA abundance (occurring within $15 \mathrm{~min}$ ), and the maximum accumulation occurs between 1 and $2 \mathrm{~h}$. The increased $\beta 2$ adrenergic receptor mRNA abundance then slowly decays back to control values by $10 \mathrm{~h}$ in the continued presence of glucocorticoid. We could not detect an increase in mRNA level at this early time; however, while the increased expression developed more slowly, the maximum value remained increased for a much longer time (at least $48 \mathrm{~h}$ ). These differences between the accumulation of $\beta 2$ adrenergic receptor mRNA and that of the $\alpha 1 \mathrm{~B}$ adrenergic receptor mRNA may be, at least in part, due to the greater stability of the latter in these cells. There was a good correlation between the increase in expression of $\alpha 1 \mathrm{~B}$ adrenergic receptor and the change in abundance of the receptor's mRNA.

Gene transcriptional regulation by steroids requires the interaction of the hormone-intracellular receptor complex with cis-regulatory sequences $(25,26)$. The transcriptional induction by glucocorticoids through the glucocorticoid response element is generally rapid and does not require new protein synthesis (27). The specificity of the elements for this steroid hormone receptor is not tightly restricted, and these elements are able to mediate induction by several hormones $(28,29)$. While no clear consensus sequence has yet been defined for the androgen receptor response element, a glucocorticoid response element 15 -mer is able to mediate induction by androgens (30). As the DNA sequence of the $5^{\prime}$ flanking region of $\alpha 1 \mathrm{~B}$ adrenergic receptor gene has not been reported, we do not know whether glucocorticoid receptors and androgen receptors bind to the same or different DNA elements in this gene.

It is of interest to speculate that these effects of steroid hormones found in transformed smooth muscle cells could have relevance to changes in vascular smooth muscle that occur in certain forms of endocrine excess. There is extensive evidence that glucocorticoids enhance the sensitivity of the blood vessels to vasoconstriction induced by catecholamines (2-4). Indeed, patients with Cushing's syndrome have been found to have increased sensitivity to norepinephrine-induced pressor responses (1). On the other hand, it is likely that the hypertension so commonly seen in Cushing's syndrome is multifactorial, involving changes in salt balance, renin-angiotensin system, as well as effects on vasodilating mechanisms such as those mediated by prostaglandins and the kallikrein-kinin systems (1). While some of the effects of excess concentrations of glucocorticoids occur within minutes, there is evidence that glucocorticoids are important in the maintenance of a normal complement of $\alpha 1$ adrenergic receptors in blood vessels from rats (31). While testosterone has been found to increase sensitivity of blood vessels to constriction induced by catecholamines, in one study in rats, this was found to be due to a change in receptor affinity for catecholamines rather than receptor number (32). Testosterone increases expression of the $\beta 2$ adrenergic receptor gene in prostate (33). The fact that the expression of the $\alpha 1 \mathrm{~B}$ receptor gene is increased by aldosterone raises the possibility that changes in these receptors in vascular smooth muscle could contribute to mineralocorticoid-induced hypertension. However, it is possible that the action of aldosterone in DTT1 MF-2 cells may involve activation of a glucocorticoid receptor. These possibilities require direct experimental testing in animal and possibly human subjects.

We have found that the expression of the $\alpha 1 \mathrm{~B}$ adrenergic receptor gene is induced by glucocorticoids and results in an increase in the number of $\alpha 1 \mathrm{~B}$ adrenergic receptors. Even after $48 \mathrm{~h}$ exposure to dexamethasone, receptor number and mRNA abundance remained increased. While these changes have interest in their own right, they are raise the possibility that these types of changes could contribute to the increased sensitivity to catecholamines that is seen in certain forms of endocrine hypertension.

\section{Acknowledgments}

We thank Dr. Robert J. Lefkowitz and colleagues at Duke University for providing the $\alpha 1 \mathrm{~B}$ adrenergic receptor cDNA probe, and Dr. Gordon Ringold, Syntex Corp., and Dr. Sheila Collins, Duke University, for their helpful suggestions.

This work was supported by National Institutes of Health grant HL-41315 and the Research Service of the Veterans Administration. Dr. Motoyoshi Sakaue is supported in part by a Dean's postdoctoral fellowship (Stanford University). Dr. Brian B. Hoffman is an Established Investigator of the American Heart Association.

\section{References}

1. Saruta, T., H. Suzuki, M. Handa, Y. Igarashi, K. Kondo, and S. Senba. 1986. Multiple factors contribute to the pathogenesis of hypertension in Cushing's syndrome. J. Clin. Endocrinol. Metab. 62:275-279.

2. Kadowitz, P. J., and A. C. Yard. 1971. Influence of hydrocortisone on cardiovascular responses to epinephrine. Eur. J. Pharmacol. 13:281-286.

3. Yard, A. C., and P. J. Kadowitz. 1972. Studies on the mechanism of hydrocortisone potentiation of vasoconstrictor responses to epinephrine in the anesthetized animal. Eur. J. Pharmacol. 20:1-9.

4. Besse, J. C., and A. D. Bass. 1966. Potentiation by hydrocortisone of responses to catecholamines in vascular smooth muscle. J. Pharmacol. Exp. Ther 154:224-238.

5. Minneman, K. P. 1988. Alpha1-adrenergic receptor subtypes, inositol phosphates, and sources of cell $\mathrm{Ca}^{2+}$. Pharmacol. Rev. 540:87-119.

6. Han, C., P. W. Abel, and P. K. Minneman. 1987. Alphal-adrenoceptor subtypes linked to different mechanisms for increasing intracellular $\mathrm{Ca}^{2+}$ in smooth muscle. Nature (Lond.). 329:333-335.

7. Cotecchia, S., D. A. Schwinn, R. R. Randall, R. J. Lefkowitz, M. G. Caron, and B. K. Kobilka. 1988. Molecular cloning and expression of the cDNA for the hamster alphal-adrenergic receptor. Proc. Natl. Acad. Sci. USA. 85:7159-7163. 
8. Schwinn, D. A., J. W. Lomasney, W. Lorenz, P. J. Szklut, R. T. Fremeau, T. L. Yang-Feng, M. G. Caron, R. J. Lefkowitz, and S. Cotecchia. 1990. Molecular cloning and expression of the cDNA for a novel alphal-adrenergic receptor subtype. J. Biol. Chem. 265:8183-8189.

9. Burnstein, K. L., and J. A. Cidlowski. 1989. Regulation of gene expression by glucocorticoids. Annu. Rev. Physiol. 51:683-699.

10. Collins, S., M. G. Caron, and R. J. Lefkowitz. 1988. Beta2-adrenergic receptors in hamster smooth muscle cells are transcriptionally regulated by glucocorticoids. J. Biol. Chem. 263:9067-9070.

11. Hadcock, J. R., and C. C. Malbon. 1988. Regulation of beta-adrenergic receptors by "permissive" hormones: glucocorticoids increase steady-state levels of receptor mRNA. Proc. Natl. Acad. Sci. USA. 85:8415-8419.

12. Jazayeri, A., and W. J. Meyer, III. 1988. Glucocorticoid modulation of beta-adrenergic receptors of cultured rat arterial smooth muscle cells. Hypertension (Dallas). 12:393-398.

13. Peterson, G. L. 1977. A simplification of the protein assay method of Lowry et al. which is more generally applicable. Anal. Biochem. 83:346-356.

14. Drubin, D. G., D. Caput, and M. W. Kirschner. 1984. Studies on the expression of the microtubule-associated protein, tau, during mouse brain development, with newly isolated complementary DNA probes. J. Cell Biol. 98:10901097

15. Davis, L. G., M. D. Dibner, and J. F. Battey. 1986. Basic Methods in Molecular Biology. Elsevier Science Publishing Co., Inc., New York. 388 pp.

16. Gunning, P., P. Ponte, H. Okayama, J. Engel, H. Blau, and L. Kedes. 1983. Isolation and characterization of full-length cDNA clones for human alpha-, beta-, and gamma-actin mRNAs: skeletal but not cytoplasmic actins have an amino-terminal cysteine that is subsequently removed. Mol. Cell. Biol. 3:787795.

17. Greenberg, M. E., and E. B. Ziff. 1984. Stimulation of 3T3 cells induces transcription of the c-fos proto-oncogene. Nature (Lond.). 311:433-438.

18. Rodgers, J. R., M. L. Johnson, and J. M. Rosen. 1985. Measurement of mRNA concentration and mRNA half-life as a function of hormonal treatment. Methods Enzymol. 109:572-592.

19. Norris, J. S., J. Gorski, and P. O. Kohler. 1974. Androgen receptors in a Syrian hamster ductus deferens tumour cell line. Nature (Lond.). 248:422-424.

20. Cornett, L. E., and J. S. Norris. 1982. Characterization of the alphaladrenergic receptor subtype in a smooth muscle cell line. J. Biol. Chem. 257:6946797.
21. Norris, J. S., and P. O. Kohler. 1983. Syrian hamster glucocorticoid receptors: characteristics on binding of partially purified receptor to DNA. J. Biol. Chem. 258:2350-2356.

22. Norris, J. S., D. J. Garmer, F. Brown, K. Popovich, and L. E. Cornett. 1983. Characteristics of an adenylate cyclase coupled beta 2-adrenergic receptor in a smooth muscle tumor cell line. $J$. Recept. Res. 3:623-645.

23. Ringold, G. M. 1985 . Steroid hormone regulation of gene expression Annu. Rev. Pharmacol. Toxicol. 25:529-566.

24. Palmiter, R. D., and N. H. Carey. 1974. Rapid inactivation of ovalbumin messenger ribonucleic acid after acute withdrawal of estrogen. Proc. Natl. Acad. Sci. USA. 71:2357-2361.

25. Beato, M. 1989. Gene regulation by steroid hormones. Cell. 56:335-344.

26. Yamamoto, K. R. 1985. Steroid receptor regulated transcription of specific genes and gene networks. Annu. Rev. Genet. 19:209-215.

27. Groner, B., N. E. Hynes, U. Rahmsdorf, and H. Ponta. 1983. Transcription initiation of transfected mouse mammary tumor virus LTR DNA is regulated by glucocorticoid hormones. Nucleic Acids Res. 11:4713-4725.

28. von der Ahe, D., S. Janich, C. Scheidereit, R. Renkawitz, G. Schuz, and M. Beato. 1985. Glucocorticoid and progesterone receptors bind to the same sites in two hormonally regulated promoters. Nature (Lond.). 313:706-709.

29. Cato, A. C., P. Skroch, J. Weinmann, P. Butkeraitis, and H. Ponta. 1988. DNA sequences outside the receptor-binding sites differently modulate the responsiveness of the mouse mammary tumour virus promoter to various steroid hormones. EMBO (Eur. Mol. Biol. Organ.) J. 7:1403-1410.

30. Ham, J., A. Thomson, M. Needham, P. Webb, and M. Parker. 1988. Characterization of response elements for androgens, glucocorticoids and progestins in mouse mammary tumour virus. Nucleic Acids Res. 16:5263-5276.

31. Haigh R. M., and C. T. Jones. 1990. Effect of glucocorticoids on alpha1adrenergic receptor binding in rat vascular smooth muscle. J. Mol. Endocrinol. $5: 41-48$

32. Colucci, W. S., M. A. Gimbrone, Jr., M. K. McLaughlin, W. Halpern, and R. W. Alexander. 1982. Increased vascular catecholamine sensitivity and alphaadrenergic receptor affinity in female and estrogen-treated male rats. Circ. Res. 50:805-811

33. Collins, S., V. E. Quarmby, F. S. French, R. J. Lefkowitz, and M. G. Caron. 1988. Regulation of the beta2-adrenergic receptor and its mRNA in the rat ventral prostate by testosterone. FEBS (Fed. Eur. Biol. Soc.) Lett. 233:173176. 